\title{
Evaluasi Dan Studi Persepsi Terhadap Tingkat Pelayanan Jalur Pejalan Kaki Kawasan Pendidikan
}

\author{
Nurul Adhaini ${ }^{1}$, Yossyafra ${ }^{2}$, Purnawan $^{3}$ \\ Fakultas Teknik, Universitas Andalas, Padang ${ }^{1}$, Dosen Fakultas Teknik, Universitas Andalas, \\ Padang ${ }^{2,3}$ \\ Email: nuruladhaini82@gmail.com ${ }^{1}$,yossyafra@ft.unand.ac.id ${ }^{2}$,purnawan@gmail.com ${ }^{3}$
}

DOI: http://dx.doi.org/10.31869/rtj.v3i2.1783

\begin{abstract}
Ade Irma Suryani street is one of the area in Payakumbuh city that is designed as an area which mainly function as educational and others such as offices and health service area. Educational infrastructure on this street includes Public Primary School 04 Payakumbuh, Raudhatul Jannah Payakumbuh Islamic Middle School, Campus II Andalas University Payakumbuh and PAUD Bakti Pediatrics. Educational, offices and health service infrastructure encourage the society to use the pedestrian pathways. The existing condition of infrastructure and facilities are still considered inadequate with various problems. This research aim to evaluate the level of service of pedestrian pathways, to review public perception of pedestrian pathways service, and to set the primary variable for the enhancement of pedestrian pathways based on user perception. The quotation of the level of pedestrian service is based on Minister of Public Works Regulation Number: 03/PRT/M/2014. Characteristic analysis result stated that the level of service on the north side is regarded as " $A$ ". While the level of service on the south side is regarded as "B". Public perception analysis of pedestrian pathways service is carried using the Importance Performance Analysis (IPA) method, with 6 research variable namely accessibility, safety, comfort, aestethic, convenience and social interactions. The result of the analysis stated that the primary priorities are accessibilty, aesthetic, convenience and social interactions, the variable which need maintance in it's performance is safety and the variable which considered excessive is comfort.
\end{abstract}

Keywords : Pedestrian pathway, level of service, Importance Performance Analysis (IPA)

\section{PENDAHULUAN}

Berdasarkan Rencana Tata Ruang Wilayah Kota Payakumbuh Tahun 2010 - 2030 jalan Ade Irma Suryani merupakan salah satu kawasan di kota Payakumbuh yang fungsi utamanya diarahkan sebagai kawasan pendidikan dan fungsi lainnya seperti perkantoran dan pelayanan kesehatan. Prasarana pendidikan pada ruas jalan ini diantaranya yaitu SD Negeri 04 Payakumbuh, SMP Islam Raudhatul Jannah Payakumbuh, Kampus II Universitas Andalas Payakumbuh dan PAUD Bakti Pediatrika. Disamping itu, jalan ini merupakan jalan utama menuju Rumah Sakit Umum Daerah DR Adnaan WD Kota Payakumbuh.

Berdasarkan Rencana Tata Ruang Wilayah Kota Payakumbuh Tahun 2010 - 2030 jalan Ade Irma Suryani merupakan salah satu kawasan di kota Payakumbuh yang fungsi utamanya diarahkan sebagai kawasan pendidikan dan fungsi lainnya seperti perkantoran dan pelayanan kesehatan. Prasarana pendidikan pada ruas jalan ini diantaranya yaitu SD Negeri 04 Payakumbuh, SMP Islam Raudhatul Jannah Payakumbuh, Kampus II Universitas Andalas Payakumbuh dan PAUD Bakti Pediatrika. Disamping itu, jalan ini merupakan jalan utama menuju Rumah Sakit Umum Daerah DR Adnaan WD Kota Payakumbuh.

Pemerintah daerah pun cenderung berinvestasi terbatas terhadap lingkungan jalan dan kebutuhan pejalan kaki. Perencanaan transportasi dan lalu lintas sebagian besar diarahkan pada lalu lintas kendaraan bermotor. Akibatnya, berbagai masalah terus menerus muncul dan harus dihadapi para pejalan kaki. Sehingga perlu dilakukan penelitian untuk mengevaluasi tingkat pelayanan jalur pejalan kaki, mengkaji persepsi masyarakat terhadap pelayanan jalur pejalan kaki dan menetapkan variabel prioritas untuk peningkatan pelayanan jalur pejalan kaki berdasarkan persepsi pengguna jalur pejalan kaki pada jalan Ade Irma Suryani kota Payakumbuh.

\begin{tabular}{llr}
\hline ISSN 2599-2081 & Fakultas Teknik UMSB & 213 \\
EISSN 2599-2090 &
\end{tabular}


Jalur pejalan kaki adalah ruang yang digunakan untuk berjalan kaki atau berkursi roda bagi penyandang disabilitas secara mandiri dan dirancang berdasarkan kebutuhan orang untuk bergerak aman, mudah, nyaman dan tanpa hambatan. Jalur pejalan kaki merupakan ruang dari koridor sisi jalan yang secara khusus digunakan untuk area pejalan kaki. Trotoar merupakan jalur pejalan kaki yang sejajar dengan sumbu jalan dan lebih tinggi dari permukaan perkerasan jalan untuk menjamin keselamatan pejalan kaki dalam rencana tata ruang (Permen PU, 2014).

Dasar penentuan tingkat pelayanan jalur pejalan kaki yaitu :

a. Highway Capacity Manual 2000

Tingkat pelayanan jalur pejalan kaki menurut HCM 2000 terdapat pada Tabel 1.

Tabel 1 Tingkat pelayanan jalur pejalan kaki (HCM 2000)

\begin{tabular}{|c|c|c|c|c|}
\hline \multirow{2}{*}{ LOS } & \multirow{2}{*}{$\begin{array}{c}\text { Ruang } \\
\left(\mathbf{m}^{2} /\right. \\
\text { orang) }\end{array}$} & $\begin{array}{c}\text { Kecepa } \\
\text { t- } \\
\text { an } \\
\text { (m/dtk) }\end{array}$ & $\begin{array}{c}\text { Arus dan Kecepatan yang } \\
\text { (Orang/ } \\
\text { menit/m }\end{array}$ & $\begin{array}{c}\text { Volume } \\
\text { Arus/ } \\
\text { Kapasit } \\
\text { as }\end{array}$ \\
\hline A & $>5.60$ & $>1.30$ & $\leq 16$ & $\leq 0.21$ \\
\hline B & $>3.70$ & $>1.27-$ & $>16-23$ & $>0.21-$ \\
& -5.60 & 1.30 & & 0.31 \\
\hline C & $>2.20$ & $>1.22-$ & $>23-33$ & $>0.31-$ \\
& -3.70 & 1.27 & & 0.44 \\
\hline D & $>1.40$ & $>1.14-$ & $>33-49$ & $>0.44-$ \\
& -2.20 & 1.22 & & 0.65 \\
\hline E & $>0.75$ & $>0.75-$ & $>49-75$ & $>0.65-$ \\
& -1.40 & 1.14 & & 1.00 \\
\hline F & $\leq 0.75$ & $\leq 0.75$ & Ber- & Ber- \\
& & & variasi & variasi \\
\hline
\end{tabular}

Sumber : US Highway Capacity Manual (2000)

Penelitian terdahulu yang menggunakan HCM 2000 sebagai dasar penentuan tingkat pelayanan dilakukan oleh Limpong (2015) meneliti pemodelan arus fasilitas pejalan kaki, menganalisis karakteristik tingkat pelayanan pejalan kaki dan walkability dengan hasil analisis tingkat pelayanan jalur pejalan kaki pada level A. Dan Wiyana (2010) melakukan penelitian tentang analisis fasilitas pejalan kaki pada ruas jalan Gajah Mada Denpasar Bali, menganalisis karakteristik pejalan kaki dan fasilitas pejalan kaki, dengan hasil analisis tingkat pelayanan jalur pejalan kaki pada level A.

b. Peraturan Menteri Pekerjaan Umum Nomor 03/PRT/M/2014

Tingkat pelayanan jalur pejalan kaki menurut Permen PU nomor: 03/PRT/M// 2014 dapat dilihat pada Tabel 2.

Tabel 2 Tingkat pelayanan jalur pejalan kaki (Permen PU No : 03/PRT/M/2014)

\begin{tabular}{|c|c|c|c|c|}
\hline $\begin{array}{c}\text { LO } \\
\text { S }\end{array}$ & $\begin{array}{c}\text { Jalur } \\
\text { Pejala } \\
\mathbf{n} \\
\text { Kaki } \\
\left(\mathbf{m}^{2} /\right. \\
\text { orang) }\end{array}$ & $\begin{array}{c}\text { Kecepat } \\
- \\
\text { an Rata- } \\
\text { Rata } \\
\text { (meter/ } \\
\text { menit) }\end{array}$ & $\begin{array}{c}\text { Volume } \\
\text { Arus } \\
\text { Pejalan } \\
\text { Kaki } \\
\text { (org/ m/ } \\
\text { mnt) }\end{array}$ & $\begin{array}{c}\text { Volume/ } \\
\text { Kapasit } \\
\text { as Rasio }\end{array}$ \\
\hline A & $\geq 12$ & $\geq 78$ & $\leq 6.7$ & $\leq 0.08$ \\
\hline B & $\geq 3.6$ & $\geq 75$ & $\leq 23$ & $\leq 0.28$ \\
\hline C & $\geq 2.2$ & $\geq 72$ & $\leq 33$ & $\leq 0.40$ \\
\hline D & $\geq 1.4$ & $\geq 68$ & $\leq 50$ & $\leq 0.60$ \\
\hline E & $\geq 0.5$ & $\geq 45$ & $\leq 83$ & $\leq 1.00$ \\
\hline F & $<0.5$ & $<45$ & variabel & 1.00 \\
\hline \multicolumn{3}{|c|}{ Sumber : Permen $P U(2014)$} \\
\end{tabular}

Penelitian terdahulu yang menggunakan Permen PU nomor : 03/PRT/M/2014 sebagai dasar penentuan tingkat pelayanan dilakukan oleh Irawan (2017) melakukan penelitian tentang analisis karakteristik, tingkat pelayanan fasilitas pejalan kaki di kawasan pasar Gede kota Surakarta, membandingkan tingkat pelayanan fasilitas pejalan kaki menurut Permen PU nomor : 03/PRT/M/2014 dengan standar tingkat pelayanan fasilitas pejalan kaki dari Bangkok, Thailand dan Australia. Dan Ferdiansyah (2017) meneliti tentang identifikasi tingkat pelayanan fasilitas pejalan kaki di kawasan komplek Gor H. Agus Salim kota Padang, dengan membandingkan kebutuhan jalur pejalan kaki, dengan standar sarana, ruang bebas pejalan kaki, tingkat kepuasan dan diperoleh tingkat pelayanan prasarana memuaskan dan tingkat LOS B.

\section{METODE PENELITIAN}

Penelitian ini mendeskripsikan nilai-nilai suatu variabel dari suatu populasi dengan cara sistematis tanpa menguji hipotesis. Penelitian yang digunakan adalah Penelitian Survei yang bertujuan mengumpulkan informasi tentang variabel dari sampel populasi yang mewakili dari wilayah studi. Data yang dibutuhkan dalam penelitian ini tidak hanya data primer tetapi juga data sekunder. Data sekunder 
diperoleh dalam bentuk yang sudah jadi, sudah dikumpulkan dan sudah diolah oleh pihak lain, biasanya dalam bentuk publikasi dan dipakai sebagai data pendukung dari data primer, seperti : data tata guna lahan dari kawasan penelitian, data tentang disain geometrik jalan eksisting dari kawasan penelitian dan data peta dari kawasan penelitian.

Penelitian dilakukan melalui beberapa tahapan yang tergambar pada Gambar 1 .

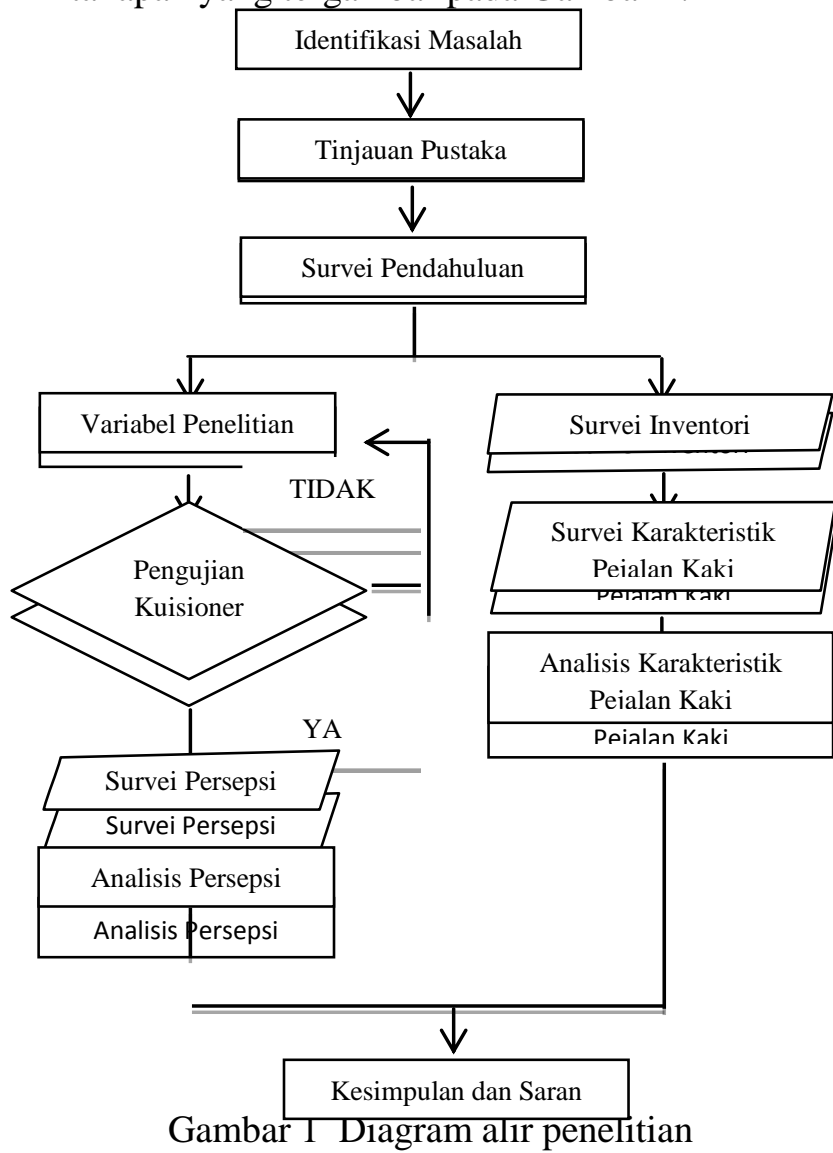

\section{Survei Karakteristik Pejalan Kaki}

Penelitian ini dilakukan pada jalur pejalan kaki di jalan Ade Irma Suryani. Volume pejalan kaki diambil dari pejalan kaki di area survei dengan panjang pengamatan 100 meter dari STA 225 sampai STA 325 pada masingmasing sisi jalur pejalan kaki.

Survei volume pejalan kaki dilaksanakan selama satu hari (12 jam) dari pukul 06.00 WIB sampai dengan 18.00 WIB, dengan cara mencatat jumlah pejalan kaki yang melewati penggal pengamatan dalam interval waktu 15 menit. Survei Waktu tempuh pejalan kaki diambil sebanyak 5 orang sampel per 15 menit dengan jarak tempuh 10 meter.

\section{Analisis Karakteristik Pejalan Kaki}

Analisis tingkat pelayanan jaringan pejalan kaki ini berdasarkan Tingkatan Standar Pelayanan Jalur Pejalan Kaki yang terdapat pada Peraturan Menteri Pekerjaan Umum Nomor : 03/PRT/M/2014. Karakteristik pejalan kaki yang dianalisa adalah : arus, kecepatan, kepadatan, ruang dan volume/ kapasitas rasio pejalan kaki. Perhitungan analisis karakteristik pejalan kaki pejalan kaki untuk menentukan tingkat pelayanan jalur pejalan kaki dilakukan hanya pada jam puncak. Perhitungan arus, kecepatan, kepadatan dan ruang menggunakan rumus pada Highway Capacity Manual 2000.

\section{Survei Persepsi Masyarakat}

Jumlah populasi untuk survei persepsi diambil dari data survei volume pejalan kaki. Penentuan jumlah sampel menggunakan rumus Slovin. Untuk pengambilan sampel digunakan metode proportional stratified random sampling menggunakan rumus alokasi proporsional (Cadima et al, 2005).

Penilaian kuesioner menggunakan skala Likert sebanyak lima tingkat (Simanjuntak, 2011). Untuk menjamin data yang dikumpulkan tidak bias, dilakukan pengujian validitas dan reliabilitas.

Variabel dan indikator yang digunakan dalam penelitian ini tersaji pada Tabel 3 .

Tabel 3 Variabel penelitian

\begin{tabular}{|c|l|l|}
\hline $\begin{array}{c}\mathbf{N} \\
\mathbf{0}\end{array}$ & Variabel & \multicolumn{1}{|c|}{ Indikator } \\
\hline 1 & Aksesibilita & $\begin{array}{l}\text { Tingkat aksesibilitas jalur } \\
\text { pejalan kaki oleh seluruh } \\
\text { pengguna termasuk pejalan } \\
\text { kaki dengan berbagai } \\
\text { keterbatasan fisik }\end{array}$ \\
\hline 2 & $\begin{array}{l}\text { Keselamata } \\
\mathrm{n}\end{array}$ & $\begin{array}{l}\text { Tingkat keselamatan } \\
\text { ditinjau dari ruang pejalan } \\
\text { kaki terpisah dari jalur lalu } \\
\text { lintas kendaraan dan } \\
\text { memiliki ketinggian berbeda }\end{array}$ \\
\hline 3 & $\begin{array}{l}\text { Kingkat kenyamanan } \\
\text { ditinjau dari lebar yang } \\
\text { nyaman, jalur pejalan kaki } \\
\text { memiliki permukaan yang } \\
\text { tidak licin }\end{array}$ \\
\hline 4 & Keindahan & $\begin{array}{l}\text { Tingkat keindahan ditinjau } \\
\text { dari ruang pejalan kaki } \\
\text { memiliki material penutup } \\
\text { yang berpola dan memiliki }\end{array}$ \\
\hline
\end{tabular}




\begin{tabular}{|l|l|l|}
\hline & & daya serap yang tinggi \\
\hline 5 & $\begin{array}{l}\text { Kemudaha } \\
\mathrm{n}\end{array}$ & $\begin{array}{l}\text { Tingkat kemudahan ditinjau } \\
\text { dari jalur yang mudah } \\
\text { dicapai dan tidak terhalangi } \\
\text { oleh apapun dan jalur yang } \\
\text { menerus dari titik satu ke } \\
\text { titik lainnya }\end{array}$ \\
\hline 6 & $\begin{array}{l}\text { Tnteraksi } \\
\text { Sosial }\end{array}$ & $\begin{array}{l}\text { ditinaau interaksi dari jalur yang } \\
\text { memiliki titik-titik untuk } \\
\text { dapat melakukan interaksi } \\
\text { sosial lengkap dengan } \\
\text { fasilitasnya }\end{array}$ \\
\hline
\end{tabular}

Masing-masing variabel penelitian pada Tabel 3 dirinci menjadi lima ukuran indikator. Jadi kuesioner penelitian ini terdiri atas 6 variabel yang diukur dengan 30 ukuran indikator/ pertanyaan.

\section{Analisis Data Persepsi Masyarakat}

Metode analisis yang dipilih dalam penelitian ini adalah Importance-Performance Analysis. Dengan cara menghitung nilai ratarata tingkat kepentingan dengan kinerja. Penggunaan nilai rata-rata dipilih karena dalam perhitungan lebih mudah digunakan, mempertimbangkan semua nilai data dan data yang tersedia tidak ekstrim.

IPA merupakan suatu teknik analisis yang digunakan untuk mengidentifikasi faktorfaktor kinerja penting yang harus diberikan oleh pemberi jasa untuk memenuhi kepuasan para pengguna jasa. Terlebih dahulu ditetapkan variabel-variabel yang mempengaruhi tingkat pelayanan. Kemudian responden diminta untuk menilai tingkat kinerja/ kenyataan (performance) dan tingkat kepentingan/ harapan (importance) dari pelayanan. Hasil dari IPA ditampilkan dalam bentuk kuadran 2 dimensi yang mudah diinterpretasi pada Gambar 2.

\section{Extremelly Important}

\begin{tabular}{|l|l|}
\hline $\begin{array}{l}\text { A. Concentrate } \\
\text { Here }\end{array}$ & $\begin{array}{l}\text { B. Keep Up The } \\
\text { Good Work }\end{array}$ \\
\hline B. & $\begin{array}{l}\text { D. Possible } \\
\text { Overkill }\end{array}$ \\
\hline
\end{tabular}

Slightly Importance

Gambar 2 Diagram Kartesius IPA

(Sumber : Martilla ,1977)

Penjelasan dari rincian masing-masing kuadran yang ada pada gambar 2.1 diatas adalah sebagai berikut :

a. Kuadran I : Prioritas Utama

Variabel pada kuadran ini dianggap sebagai variabel yang penting oleh pengguna tetapi kondisi kinerja tidak baik. Variabelvariabel pada kuadran ini menjadi variabel prioritas untuk ditingkatkan.

b. Kuadran II : Pertahankan Kinerja

Variabel pada kuadran ini dianggap sebagai variabel yang penting oleh pengguna dengan kondisi kinerja yang sangat baik. Variabel-variabel pada kuadran ini harus dipertahankan.

c. Kuadran III : Prioritas Rendah

Variabel pada kuadran ini dianggap sebagai variabel yang kurang penting oleh pengguna dengan kondisi kinerja yang juga tidak baik. Variabel-variabel pada kuadran ini perlu dipertimbangkan untuk ditingkatkan karena pengaruh manfaatnya terhadap pengguna tidak begitu besar.

d. Kuadran IV : Terlalu berlebih

Variabel pada kuadran ini dianggap sebagai variabel yang tidak penting oleh pengguna dengan kondisi kinerja yang baik atau berlebihan. Variabel-variabel pada kuadran ini dapat dikurangi dan dialihkan untuk kuadran I dan II.

\section{HASIL DAN PEMBAHASAN}

Data Karakteristik Pejalan Kaki

Data Volume Pejalan Kaki

Volume puncak dan waktu puncak pejalan kaki dapat dilihat pada Tabel 4.

Tabel 4 Volume puncak pejalan kaki

\begin{tabular}{|c|c|c|c|c|c|}
\hline \multirow{2}{*}{$\begin{array}{c}\text { Wakt } \\
\mathrm{u}\end{array}$} & \multicolumn{2}{|c|}{ Sisi Utara } & \multirow[b]{2}{*}{ Waktu } & \multicolumn{2}{|c|}{ Sisi Selatan } \\
\hline & Total & $\begin{array}{l}\text { Kumu- } \\
\text { latif }\end{array}$ & & Total & $\begin{array}{l}\text { Kumu- } \\
\text { latif }\end{array}$ \\
\hline
\end{tabular}


Vol. 3 No.2 Juni 2020

http://jurnal.umsb.ac.id/index.php/RANGTEKNIKJOURNAL

\begin{tabular}{|c|c|c|c|c|c|}
\hline $\begin{array}{l}10.30 \\
- \\
10.45\end{array}$ & 21 & 42 & $\begin{array}{l}16.00- \\
16.15\end{array}$ & 70 & 83 \\
\hline $\begin{array}{l}10.45 \\
- \\
11.00\end{array}$ & 23 & 56 & $\begin{array}{l}16.15- \\
16.30\end{array}$ & 90 & 167 \\
\hline $\begin{array}{l}11.00 \\
- \\
11.15\end{array}$ & 33 & 84 & $\begin{array}{l}16.30- \\
16.45\end{array}$ & 112 & 274 \\
\hline $\begin{array}{l}11.15 \\
- \\
11.30\end{array}$ & 19 & 96 & $\begin{array}{l}16.45- \\
17.00\end{array}$ & 56 & 328 \\
\hline
\end{tabular}

Data Waktu Tempuh Pejalan Kaki

Data waktu tempuh pejalan kaki pada jam puncak dapat dilihat pada Tabel 5.

Tabel 5 Data waktu tempuh pejalan kaki

\begin{tabular}{|c|c|c|c|c|c|c|c|c|c|c|c|}
\hline \multirow{4}{*}{$\begin{array}{c}\text { Wakt } \\
\text { u }\end{array}$} & \multirow{3}{*}{\multicolumn{2}{|c|}{$\begin{array}{c}\text { Waktu } \\
\text { tempuh } \\
\text { pejalan kaki } \\
\text { (ti) (detik) }\end{array}$}} & \multirow{4}{*}{$\begin{array}{c}\text { Wakt } \\
\text { u }\end{array}$} & \multirow{3}{*}{\multicolumn{2}{|c|}{$\begin{array}{c}\text { Waktu } \\
\text { tempuh } \\
\text { pejalan kaki } \\
\text { (ti) (detik) }\end{array}$}} & \multirow{3}{*}{$11 . \overline{30}$} & \multirow{3}{*}{$\begin{array}{l}4 \\
5\end{array}$} & \multirow{3}{*}{$\begin{array}{c}9 \\
11.4 \\
5 \\
10.6 \\
6 \\
\end{array}$} & \multirow{3}{*}{17.00} & \multirow[b]{2}{*}{4} & \multirow{2}{*}{$\begin{array}{l}10.56 \\
10.98 \\
\end{array}$} \\
\hline & & & & & & & & & & & \\
\hline & & & & & & & & & & 5 & 10.56 \\
\hline & $\begin{array}{l}\text { Nomo } \\
\mathbf{r} \\
\text { sampe } \\
\quad l\end{array}$ & $\begin{array}{c}\text { Sisi } \\
\text { utar } \\
\text { a }\end{array}$ & & $\begin{array}{l}\text { Nomo } \\
\mathbf{r} \\
\text { sampe } \\
\mathbf{l}\end{array}$ & $\begin{array}{c}\text { Sisi } \\
\text { selata } \\
\text { n }\end{array}$ & \multirow{4}{*}{\multicolumn{6}{|c|}{$\begin{array}{l}\text { 3.2 Analisis Karakteristik Pejalan Kaki } \\
\text { 3.2.1 Analisis Arus Pejalan Kaki } \\
\text { Hasil perhitungan volume arus pada sisi } \\
\text { utara dan sisi selatan dapat dilihat pada Tabel } \\
6 \text { dan Tabel } 7 \text {. }\end{array}$}} \\
\hline \multirow{5}{*}{$\begin{array}{c}10.30 \\
- \\
10.45\end{array}$} & 1 & $\begin{array}{c}11.3 \\
1 \\
\end{array}$ & \multirow{5}{*}{$\begin{array}{c}16.00 \\
- \\
16.15\end{array}$} & 1 & 9.56 & & & & & & \\
\hline & 2 & $\begin{array}{c}10.2 \\
3 \\
\end{array}$ & & 2 & 8.98 & & & & & & \\
\hline & 3 & $\begin{array}{c}11.3 \\
4 \\
104\end{array}$ & & 3 & 8.76 & & & & & & \\
\hline & 4 & $\begin{array}{c}10.4 \\
1\end{array}$ & & 4 & 9.43 & \multirow{6}{*}{$\begin{array}{l}\text { wakt } \\
\text { u }\end{array}$} & arus & & & & \\
\hline & 5 & $\begin{array}{c}11.4 \\
5\end{array}$ & & 5 & 10.77 & & $\begin{array}{l}\text { pejala } \\
\text { n kaki }\end{array}$ & lebar & & lebar & $\begin{array}{l}\text { arus } \\
\text { pejala }\end{array}$ \\
\hline \multirow{5}{*}{$\begin{array}{c}10.45 \\
- \\
11.00\end{array}$} & 1 & $\begin{array}{c}10.3 \\
5 \\
\end{array}$ & \multirow{5}{*}{$\begin{array}{c}16.15 \\
- \\
16.30\end{array}$} & 1 & 10.34 & & $\begin{array}{l}15 \\
\text { menit } \\
\text { ter- }\end{array}$ & $\begin{array}{l}\text { total } \\
\text { jalur } \\
\text { pejala }\end{array}$ & $\begin{array}{l}\text { lebar } \\
\text { ham- } \\
\text { batan }\end{array}$ & $\begin{array}{l}\text { efektıf } \\
\text { jalur } \\
\text { peiala }\end{array}$ & $\begin{array}{l}\text { n kaki } \\
\text { (Vped }\end{array}$ \\
\hline & 2 & $\begin{array}{c}10.4 \\
5\end{array}$ & & 2 & 11.54 & & besar & n kakI & $\left(\mathrm{W}_{\mathrm{O}}\right)$ & ( & (org/ \\
\hline & 3 & $\begin{array}{c}11.5 \\
6 \\
\end{array}$ & & 3 & 11.67 & & (org/ & (m) & & (m) & $\begin{array}{c}\mathbf{m} / \mathbf{m n} \\
\mathbf{t})\end{array}$ \\
\hline & 4 & $\begin{array}{c}11.7 \\
6\end{array}$ & & & 1076 & & ) & & & & \\
\hline & 5 & $\begin{array}{c}6 \\
10.5 \\
4 \\
\end{array}$ & & 5 & 11.76 & $\begin{array}{l}10.30 \\
- \\
10.45\end{array}$ & 21 & 1.20 & 0.48 & 0.72 & $\begin{array}{l}1.95 \approx \\
2\end{array}$ \\
\hline \multirow[t]{2}{*}{$\begin{array}{c}\text { Wakt } \\
\text { u }\end{array}$} & \multicolumn{2}{|c|}{$\begin{array}{c}\text { Waktu } \\
\text { tempuh } \\
\text { pejalan kaki } \\
\text { (ti) (detik) }\end{array}$} & \multirow{2}{*}{$\begin{array}{c}\text { Wakt } \\
\text { u }\end{array}$} & \multicolumn{2}{|c|}{$\begin{array}{c}\text { Waktu } \\
\text { tempuh } \\
\text { pejalan kaki } \\
\text { (ti) (detik) }\end{array}$} & $\begin{array}{l}10.45 \\
- \\
11.00 \\
\end{array}$ & 23 & 1.20 & 0.48 & 0.72 & $\begin{array}{l}2.13 \approx \\
2\end{array}$ \\
\hline & $\begin{array}{c}\text { Nomo } \\
\mathbf{r}\end{array}$ & $\begin{array}{l}\text { Sisi } \\
\text { utar }\end{array}$ & & $\begin{array}{c}\text { Nomo } \\
\mathbf{r}\end{array}$ & $\begin{array}{c}\text { Sisi } \\
\text { selata }\end{array}$ & $\begin{array}{l}11.00 \\
- \\
11.15\end{array}$ & 33 & 1.20 & 0.48 & 0.72 & $\begin{array}{l}3.06 \approx \\
3\end{array}$ \\
\hline
\end{tabular}

\begin{tabular}{|c|c|c|c|c|c|}
\hline & $\underset{\text { I }}{\text { sampe }}$ & $\mathbf{a}$ & & $\underset{\text { l }}{\text { sampe }}$ & $\mathbf{n}$ \\
\hline \multirow{6}{*}{$\begin{array}{c}11.00 \\
- \\
11.15\end{array}$} & 1 & $\begin{array}{c}11.3 \\
3\end{array}$ & \multirow{6}{*}{$\begin{array}{c}16.30 \\
- \\
16.45\end{array}$} & 1 & 10.56 \\
\hline & 2 & $\begin{array}{c}10.8 \\
6 \\
\end{array}$ & & 2 & 11.56 \\
\hline & 3 & $\begin{array}{c}10.5 \\
8\end{array}$ & & 3 & 1076 \\
\hline & & 11.7 & & & \\
\hline & 4 & 7 & & 4 & 10.87 \\
\hline & 5 & $\begin{array}{c}10.4 \\
3\end{array}$ & & 5 & 10.78 \\
\hline \multirow{5}{*}{$\begin{array}{c}11.15 \\
- \\
11.30\end{array}$} & 1 & $\begin{array}{c}10.5 \\
4\end{array}$ & \multirow{5}{*}{$\begin{array}{c}16.45 \\
- \\
17.00\end{array}$} & 1 & 10.32 \\
\hline & 2 & $\begin{array}{c}11.6 \\
7\end{array}$ & & 2 & 10.45 \\
\hline & 3 & $\begin{array}{c}10.0 \\
9\end{array}$ & & 3 & 10.56 \\
\hline & 4 & $\begin{array}{c}11.4 \\
5\end{array}$ & & 4 & 10.98 \\
\hline & 5 & $\begin{array}{c}10.6 \\
6\end{array}$ & & 5 & 10.56 \\
\hline
\end{tabular}


Vol. 3 No.2 Juni 2020

http://jurnal.umsb.ac.id/index.php/RANGTEKNIKJOURNAL

\begin{tabular}{|l|l|l|l|l|l|}
\hline $\begin{array}{l}11.15 \\
-11.30\end{array}$ & 19 & 1.20 & 0.48 & 0.72 & $1.76 \approx$ \\
\hline
\end{tabular}

Tabel 7 Arus pejalan kaki sisi selatan

\begin{tabular}{|c|c|c|c|c|c|}
\hline $\begin{array}{l}\text { wakt } \\
\text { u }\end{array}$ & $\begin{array}{l}\text { arus } \\
\text { pejala } \\
\text { n kaki } \\
15 \\
\text { menit } \\
\text { terbesa } \\
\mathrm{r} \\
\text { (V15) } \\
\text { (org/ } \\
\text { m/mnt } \\
\text { ) }\end{array}$ & $\begin{array}{l}\text { lebar } \\
\text { total } \\
\text { jalur } \\
\text { pejala } \\
\text { n kakI } \\
\left(\mathrm{W}_{\mathrm{T}}\right) \\
(\mathbf{m})\end{array}$ & $\begin{array}{c}\text { lebar } \\
\text { ham- } \\
\text { batan } \\
\left(\mathrm{W}_{\mathrm{O}}\right) \\
(\mathbf{m})\end{array}$ & $\begin{array}{l}\text { lebar } \\
\text { efektif } \\
\text { jalur } \\
\text { pejala } \\
\text { n kaki } \\
\left(\mathrm{W}_{\mathrm{E}}\right) \\
(\mathbf{m})\end{array}$ & $\begin{array}{l}\text { arus } \\
\text { pejala } \\
\text { n kaki } \\
\text { (Vped } \\
\text { ) } \\
\text { (org/ } \\
\mathbf{m} / \mathbf{m n} \\
\mathbf{t} \text { ) }\end{array}$ \\
\hline $\begin{array}{l}16.00 \\
- \\
16.15\end{array}$ & 70 & 1.50 & 0.73 & 0.77 & $\begin{array}{l}6.09 \approx \\
6\end{array}$ \\
\hline $\begin{array}{l}16.15 \\
-16.30\end{array}$ & 90 & 1.50 & 0.73 & 0.77 & $\begin{array}{l}7.83 \approx \\
8\end{array}$ \\
\hline $\begin{array}{l}16.30 \\
- \\
16.45\end{array}$ & 112 & 1.50 & 0.73 & 0.77 & $\begin{array}{l}9.74 \approx \\
10\end{array}$ \\
\hline $\begin{array}{l}16.45 \\
-17.00\end{array}$ & 56 & 1.50 & 0.73 & 0.77 & $\begin{array}{l}4.87 \approx \\
5\end{array}$ \\
\hline
\end{tabular}

\begin{tabular}{|c|c|c|c|c|} 
& 5 & 11.45 & 52.40 & \\
\hline \multirow{4}{*}{10.45} & 1 & 10.35 & 57.97 & \\
\cline { 2 - 4 }- & 2 & 10.45 & 57.42 & \multirow{4}{*}{54.88} \\
\cline { 2 - 4 } 11.00 & 3 & 11.56 & 51.90 & \\
\cline { 2 - 4 } & 4 & 11.76 & 51.02 & \\
\cline { 2 - 4 } & 5 & 10.54 & 56.93 & \\
\hline \multirow{4}{*}{11.00} & 1 & 10.33 & 58.08 & \multirow{4}{*}{55.59} \\
\cline { 2 - 4 }- & 2 & 10.86 & 55.25 & \\
\cline { 2 - 4 } 11.15 & 3 & 10.58 & 56.71 & \multirow{2}{*}{55.14} \\
\cline { 2 - 4 } & 4 & 11.77 & 50.98 & \\
\cline { 2 - 4 } & 5 & 10.43 & 57.53 & \\
\hline \multirow{3}{*}{11.15} & 1 & 10.54 & 56.93 & \\
- & 2 & 11.67 & 51.41 & \\
\cline { 2 - 4 } 11.30 & 3 & 10.09 & 59.46 & \\
\cline { 2 - 4 } & 4 & 11.45 & 52.40 & \\
\cline { 2 - 4 } & 5 & 10.66 & 56.29 & \\
\hline
\end{tabular}

Dari Tabel 6 diperoleh arus maksimum pada sisi utara sebesar $3 \mathrm{org} / \mathrm{m} / \mathrm{mnt}$ pada pukul 11.00 - 11.15 WIB dan dari Tabel 7 diperoleh arus maksimum pada sisi selatan sebesar 10 org/m/mnt pada pukul 16.30 - 16.45 WIB.

\section{Analisis Kecepatan Pejalan Kaki}

Hasil perhitungan kecepatan rata-rata pejalan kaki pada sisi utara pada jam puncak dapat dilihat pada Tabel 8.

Tabel 8 Kecepatan rata-rata ruang pejalan kaki sisi utara

\begin{tabular}{|c|c|c|c|c|}
\hline \multirow[b]{2}{*}{ waktu } & \multirow[b]{2}{*}{$\begin{array}{l}\text { nomor } \\
\text { sampel }\end{array}$} & \multicolumn{3}{|c|}{ sisi utara } \\
\hline & & $\begin{array}{c}\text { waktu } \\
\text { tempuh } \\
\text { pejalan } \\
\text { kaki } \\
\left(\mathbf{t}_{\mathbf{i}}\right) \\
(\text { detik) }\end{array}$ & $\begin{array}{c}\text { kecepatan } \\
\text { pejalan } \\
\text { kaki }\left(S_{i}\right) \\
(\mathbf{m} / \text { menit })\end{array}$ & $\begin{array}{c}\text { kecepatan } \\
\text { rata-rata } \\
\text { ruang } \\
\left(S_{\text {ped }}\right) \\
(\mathrm{m} / \text { menit })\end{array}$ \\
\hline \multirow{4}{*}{$\begin{array}{c}10.30 \\
- \\
10.45\end{array}$} & 1 & 11.31 & 53.05 & \multirow{4}{*}{54.80} \\
\hline & 2 & 10.23 & 58.65 & \\
\hline & 3 & 11.34 & 52.91 & \\
\hline & 4 & 10.41 & 57.64 & \\
\hline
\end{tabular}


Vol. 3 No.2 Juni 2020

http://jurnal.umsb.ac.id/index.php/RANGTEKNIKJOURNAL

Rang Teknik Journal

Tabel 9 Kecepatan rata-rata ruang pejalan kaki sisi selatan

\begin{tabular}{|c|c|c|c|c|c|c|c|c|}
\hline & \multirow{3}{*}{$\begin{array}{c}10.45- \\
11.00\end{array}$} & \multirow{3}{*}{2} & \multirow{3}{*}{54.88} & \multirow{3}{*}{0.04} \\
\hline \multirow{4}{*}{ waktu } & \multirow{4}{*}{$\begin{array}{l}\text { nomor } \\
\text { sampel }\end{array}$} & \multicolumn{3}{|c|}{ sisi selatan } & & & & \\
\hline & & \multirow{3}{*}{$\begin{array}{c}\text { waktu } \\
\text { tempuh } \\
\text { pejalan } \\
\text { kaki }\left(t_{i}\right) \\
(\text { detik })\end{array}$} & \multirow{3}{*}{$\begin{array}{c}\text { kecepatan } \\
\text { pejalan } \\
\text { kaki }\left(\mathbf{S}_{\mathbf{i}}\right) \\
(\mathbf{m} / \mathbf{m e n i t})\end{array}$} & \multirow{3}{*}{$\begin{array}{c}\text { kecepatan } \\
\text { rata-rata } \\
\text { ruang } \\
\left(S_{\text {ped }}\right) \\
(\mathrm{m} / \text { menit }) \\
\end{array}$} & & & & \\
\hline & & & & & $\begin{array}{c}11.00- \\
11.15\end{array}$ & 3 & 55.59 & 0.06 \\
\hline & & & & & $\begin{array}{c}11.15- \\
11.30 \\
\end{array}$ & 2 & 55.14 & 0.03 \\
\hline \multirow{5}{*}{$\begin{array}{c}16.00 \\
- \\
16.15\end{array}$} & 1 & 9.56 & 62.76 & \multirow{5}{*}{64.72} & \multicolumn{4}{|c|}{ Tabel 11 Kepadatan pejalan kaki sisi selatan } \\
\hline & 2 & 8.98 & 66.82 & & \multirow{8}{*}{ waktu } & & sisi selata & \\
\hline & 3 & 8.76 & 68.49 & & & arus & kecepata & \\
\hline & 4 & 9.43 & 63.63 & & & pejala & n rata- & \\
\hline & 5 & 10.77 & 55.71 & & & n kaki & & kepadata \\
\hline \multirow{5}{*}{$\begin{array}{c}16.15 \\
- \\
16.30\end{array}$} & 1 & 10.34 & 58.03 & \multirow{5}{*}{53.50} & & $\begin{array}{c}\left(V_{\text {ped }}\right) \\
(\text { orol }\end{array}$ & & $\begin{array}{l}\mathbf{n}\left(\mathbf{D}_{\text {ped }}\right) \\
\left(\mathbf{o r g} / \mathbf{m}^{2}\right)\end{array}$ \\
\hline & 2 & 11.54 & 51.99 & & & $\mathbf{m} / \mathbf{m e}$ & (m/menit & \\
\hline & 3 & 11.67 & 51.41 & & & nit) & ) & \\
\hline & 4 & 10.76 & 55.76 & & & & & \\
\hline & 5 & 11.76 & 51.02 & & $\begin{array}{c}16.00- \\
16.15\end{array}$ & 6 & 64.72 & 0.10 \\
\hline \multirow{5}{*}{$\begin{array}{c}16.30 \\
- \\
16.45\end{array}$} & 1 & 10.56 & 56.82 & \multirow{5}{*}{55.02} & & & & \\
\hline & 2 & 11.56 & 51.90 & & $16.15-$ & & 53.50 & 0.15 \\
\hline & 3 & 10.76 & 55.76 & & 16.30 & 8 & & \\
\hline & 4 & 10.87 & 55.20 & & $16.30-$ & & 5502 & 0.18 \\
\hline & 5 & 10.78 & 55.66 & & 16.45 & 10 & & \\
\hline \multirow{3}{*}{$\begin{array}{c}16.45 \\
-\end{array}$} & 1 & 11.32 & 53.00 & \multirow[b]{3}{*}{55.69} & & & & \\
\hline & 2 & 10.45 & 57.42 & & 17.00 & 5 & 55.69 & 0.09 \\
\hline & 3 & 10.56 & 56.82 & & & & & \\
\hline
\end{tabular}

17.00

$10.98 \quad 54.64$

Dari Tabel 10 diperoleh kepadatan pejalan kaki pada sisi utara sebesar $0.06 \mathrm{org} / \mathrm{m} 2$ pada pukul 11.00 - 11.15 WIB dan dari Tabel 11 diperoleh kepadatan pejalan kaki pada sisi selatan sebesar $0.18 \mathrm{org} / \mathrm{m} 2$ pada pukul 16.15 $-16.30 \mathrm{WIB}$.

\section{Analisis Ruang Pejalan Kaki}

Hasil perhitungan ruang pejalan kaki sisi utara dan selatan pada jam puncak dapat dilihat pada Tabel 12 dan Tabel 13.

Tabel 12 Ruang pejalan kaki sisi utara

Tabel 10 Kepadatan pejalan kaki sisi utara

\begin{tabular}{|c|c|c|c|}
\hline \multirow{3}{*}{ waktu } & \multicolumn{3}{|c|}{ sisi utara } \\
\hline & $\begin{array}{c}\text { arus } \\
\text { pejalan } \\
\text { kaki }\left(V_{\text {ped }}\right) \\
\left(\begin{array}{c}\text { org/m/men } \\
\text { it })\end{array}\right.\end{array}$ & $\begin{array}{c}\text { kecepata } \\
\text { n rata- } \\
\text { rata } \\
\text { ruang } \\
\left(\mathrm{S}_{\mathrm{S}}\right) \\
(\mathrm{m} / \text { menit }\end{array}$ & $\begin{array}{c}\text { Kepadat } \\
\text {-an } \\
\left(D_{\text {ped }}\right) \\
\left(\text { org } / \mathbf{m}^{2}\right)\end{array}$ \\
\hline & & ) & \\
\hline
\end{tabular}

\begin{tabular}{|c|c|c|}
\hline \multirow{2}{*}{ waktu } & \multicolumn{2}{|c|}{ sisi utara } \\
\cline { 2 - 3 } & $\begin{array}{c}\text { kepadatan } \\
\left(\mathbf{D}_{\text {ped }}\right) \\
\left(\mathbf{o r g} / \mathbf{m}^{2}\right)\end{array}$ & $\begin{array}{c}\text { ruang } \\
\text { pejalan } \\
\text { kaki }\left(\mathbf{M}_{\text {ped }}\right) \\
\left(\mathbf{m}^{2} / \mathbf{o r g}\right)\end{array}$ \\
\hline $\begin{array}{c}10.30- \\
10.45\end{array}$ & 0.04 & 28.13 \\
\hline $\begin{array}{c}10.45- \\
11.00\end{array}$ & 0.04 & 25.72 \\
\hline
\end{tabular}




\begin{tabular}{|c|c|c|}
\hline $\begin{array}{c}11.00- \\
11.15\end{array}$ & 0.06 & 18.15 \\
\hline $\begin{array}{c}11.15- \\
11.30\end{array}$ & 0.03 & 31.28 \\
\hline
\end{tabular}

Tabel 13 Ruang pejalan kaki sisi selatan

\begin{tabular}{|c|c|c|}
\hline \multirow{2}{*}{ waktu } & \multicolumn{2}{|c|}{ sisi selatan } \\
\cline { 2 - 3 } & $\begin{array}{c}\text { kepadatan } \\
\left(\mathbf{D}_{\text {ped }}\right) \\
\left(\mathbf{o r g} / \mathbf{m}^{2}\right)\end{array}$ & $\begin{array}{c}\text { ruang } \\
\text { pejalan } \\
\left.\text { kaki } \mathbf{M}_{\text {ped }}\right) \\
\left(\mathbf{m}^{2} / \mathbf{o r g}\right)\end{array}$ \\
\hline $\begin{array}{c}16.00- \\
16.15\end{array}$ & 0.10 & 10.37 \\
\hline $\begin{array}{c}16.15- \\
16.30\end{array}$ & 0.15 & 6.84 \\
\hline $\begin{array}{c}16.30- \\
16.45\end{array}$ & 0.18 & 5.65 \\
\hline $\begin{array}{c}16.45- \\
17.00\end{array}$ & 0.09 & 11.43 \\
\hline
\end{tabular}

Dari Tabel 12 diperoleh ruang/ jalur pejalan kaki pada sisi utara sebesar 18.15 m2/org pada pukul 11.00 - 11.15 WIB dan dari Tabel 13 diperoleh ruang/ jalur pejalan kaki pada sisi selatan sebesar $5.65 \mathrm{~m} 2 /$ org pada pukul $16.15-16.30 \mathrm{WIB}$.

\section{Analisis Volume/Kapasitas Rasio}

Kapasitas Rasio digunakan kapasitas jalur pejalan kaki sebesar 83 orang/meter/menit. Hasil perhitungan perhitungan Volume / Kapasitas Rasio pejalan kaki sisi utara dan selatan pada jam puncak dapat dilihat pada Tabel 14 dan Tabel 15.

Tabel 14 Volume /Kapasitas Rasio sisi utara

\begin{tabular}{|c|c|c|c|}
\hline \multirow{2}{*}{ waktu } & \multicolumn{3}{|c|}{ sisi utara } \\
\cline { 2 - 4 } & $\begin{array}{c}\text { arus } \\
\text { pejalan } \\
\text { kaki } \\
\left(\mathbf{V}_{\text {ped }}\right) \\
(\text { org/m/ } / \\
\text { menit })\end{array}$ & $\begin{array}{c}\text { kapasitas } \\
\text { (C) } \\
\text { (org/m/me } \\
\text { nit) }\end{array}$ & $\begin{array}{c}\text { v/c } \\
\text { rasio }\end{array}$ \\
\hline $\begin{array}{c}10.30- \\
10.45\end{array}$ & $\mathbf{2}$ & 83 & 0.02 \\
\hline $\begin{array}{c}10.45- \\
11.00\end{array}$ & $\mathbf{2}$ & 83 & 0.03 \\
\hline $\begin{array}{c}11.00- \\
11.15\end{array}$ & $\mathbf{3}$ & 83 & 0.04 \\
\hline $\begin{array}{c}11.15- \\
11.30\end{array}$ & $\mathbf{2}$ & 83 & 0.02 \\
\hline
\end{tabular}

Tabel 15 Volume /Kapasitas Rasio sisi selatan

\begin{tabular}{|c|c|c|c|}
\hline \multirow[b]{2}{*}{ waktu } & \multicolumn{3}{|c|}{ sisi selatan } \\
\hline & $\begin{array}{c}\text { arus } \\
\text { pejalan } \\
\text { kaki } \\
\left(\mathbf{V}_{\text {ped }}\right) \\
(\text { org/m/ } / \\
\text { menit })\end{array}$ & $\begin{array}{c}\text { kapasitas }(C) \\
(\text { org/m/menit } \\
)\end{array}$ & v/c rasio \\
\hline $\begin{array}{c}16.00- \\
16.15\end{array}$ & 6 & 83 & 0.07 \\
\hline $\begin{array}{c}16.15- \\
16.30\end{array}$ & 8 & 83 & 0.09 \\
\hline $\begin{array}{c}16.30- \\
16.45\end{array}$ & 10 & 83 & 0.12 \\
\hline $\begin{array}{c}16.45- \\
17.00\end{array}$ & 5 & 83 & 0.06 \\
\hline
\end{tabular}

Dari Tabel 14 diperoleh volume /kapasitas rasio pejalan kaki pada sisi utara sebesar 0.04 pada pukul 11.00 - 11.15 WIB dan dari Tabel 15 diperoleh ruang/ jalur pejalan kaki pada sisi selatan sebesar 0.12 pada pukul 16.15 16.30 WIB.

\section{Analisis Tingkat Pelayanan Jalur Pejalan Kaki}

Hasil perhitungan karakteristik pejalan kaki dapat dilihat pada Tabel 16 dan 17.

Tabel 16 Tingkat pelayanan jalur pejalan kaki pada sisi utara

\begin{tabular}{|c|c|c|c|c|}
\hline waktu & $\begin{array}{c}\text { ruang } \\
\text { pejalan } \\
\text { kaki } \\
\left(\mathbf{M}_{\text {ped }}\right) \\
\left(\mathbf{m}^{2} / \text { org }\right. \\
)\end{array}$ & $\begin{array}{c}\text { kecepat } \\
\text { an rata- } \\
\text { rata } \\
\text { ruang } \\
\left(\mathrm{S}_{\text {ped }}\right) \\
(\mathrm{m} / \mathrm{men} \\
\text { it }) \\
\end{array}$ & $\begin{array}{c}\text { kepadat } \\
\text { an } \\
\left(D_{\text {ped }}\right) \\
\left(\text { org } / \mathbf{m}^{2}\right. \\
)\end{array}$ & $\begin{array}{c}\text { v/c } \\
\text { rasio }\end{array}$ \\
\hline $\begin{array}{c}10.30- \\
10.45\end{array}$ & 28.13 & 54.80 & 0.04 & 0.02 \\
\hline $\begin{array}{c}10.45- \\
11.00\end{array}$ & 25.72 & 54.88 & 0.04 & 0.03 \\
\hline $\begin{array}{c}11.00- \\
11.15\end{array}$ & 18.15 & 55.59 & 0.06 & 0.04 \\
\hline $\begin{array}{c}11.15- \\
11.30\end{array}$ & 31.28 & 55.14 & 0.03 & 0.02 \\
\hline
\end{tabular}


Vol. 3 No.2 Juni 2020

http://jurnal.umsb.ac.id/index.php/RANGTEKNIKJOURNAL

Tabel 17 Tingkat pelayanan jalur pejalan kaki pada sisi selatan

\begin{tabular}{|c|c|c|c|c|}
\hline waktu & $\begin{array}{c}\text { ruang } \\
\text { pejalan } \\
\text { kaki } \\
\left(\mathbf{M}_{\text {ped }}\right) \\
\left(\mathrm{m}^{2} / \text { org }\right) \\
\end{array}$ & $\begin{array}{c}\text { kecepatan } \\
\text { rata-rata } \\
\text { ruang } \\
\left(\mathrm{S}_{\text {ped }}\right) \\
(\mathrm{m} / \text { menit }) \\
\end{array}$ & $\begin{array}{c}\text { kepadatan } \\
\left(\mathbf{D}_{\text {ped }}\right) \\
\left(\text { org/m } / \mathbf{m}^{2}\right)\end{array}$ & $\begin{array}{c}\text { v/c } \\
\text { rasio }\end{array}$ \\
\hline $\begin{array}{c}10.30 \\
- \\
10.45\end{array}$ & 10.37 & 64.72 & 0.10 & 0.07 \\
\hline $\begin{array}{c}10.45 \\
- \\
11.00\end{array}$ & 6.84 & 53.50 & 0.15 & 0.09 \\
\hline $\begin{array}{c}11.00 \\
- \\
11.15\end{array}$ & 5.65 & 55.02 & 0.18 & 0.12 \\
\hline $\begin{array}{c}11.15 \\
- \\
11.30\end{array}$ & 11.43 & 55.69 & 0.09 & 0.06 \\
\hline
\end{tabular}

Tingkat pelayanan jalur pejalan kaki pada jalan Ade Irma Suryani Kota Payakumbuh seperti terlihat pada Tabel 18 .

Tabel 18 Tingkat pelayanan jalur pejalan kaki pada jalan Ade Irma Suryani

\begin{tabular}{|l|c|c|c|c|}
\hline \multirow{2}{*}{ indikator } & \multicolumn{2}{|c|}{ sisi utara } & \multicolumn{2}{c|}{ sisi selatan } \\
\cline { 2 - 5 } & nilai & $\begin{array}{c}\text { tingkat } \\
\text { pelayanan }\end{array}$ & nilai & $\begin{array}{c}\text { tingkat } \\
\text { pelayanan }\end{array}$ \\
\hline $\begin{array}{l}\text { Ruang } \\
\left(\mathrm{m}^{2} / \mathrm{org}\right)\end{array}$ & 18.15 & $\mathrm{~A}$ & 5.65 & $\mathrm{~B}$ \\
\hline $\begin{array}{l}\text { Kecepatan } \\
\text { rata-rata } \\
\text { (m/mnt) }\end{array}$ & 55.59 & $\mathrm{E}$ & 55.02 & $\mathrm{E}$ \\
\hline $\begin{array}{l}\text { Volume } \\
\text { arus } \\
\text { (org/m/mnt) }\end{array}$ & $\mathbf{3}$ & $\mathrm{A}$ & $\mathbf{1 0}$ & $\mathrm{B}$ \\
\hline $\begin{array}{l}\text { Volume/ } \\
\text { kapasitas } \\
\text { rasio }\end{array}$ & 0.04 & $\mathrm{~A}$ & 0.12 & $\mathrm{~B}$ \\
\hline
\end{tabular}

Dari Tabel 18 dapat disimpulkan tingkat pelayanan jalur pejalan kaki pada ruas jalan Ade Irma Suryani Kota Payakumbuh pada sisi utara adalah A, sedangkan tingkat pelayanan jalur pejalan kaki pada sisi selatan adalah B.

\section{Data Survei Persepsi Masyarakat}

Data Responden

Alokasi proporsi responden dapat dilihat pada Tabel 19 di bawah ini.

Tabel 19 Alokasi proporsi responden

\begin{tabular}{|c|c|c|c|c|c|}
\hline \multirow{3}{*}{ proporsi } & \multicolumn{5}{|c|}{ responden } \\
\cline { 2 - 6 } & $\begin{array}{c}\text { Mah } \\
\text { a- }\end{array}$ & $\begin{array}{c}\text { smp } \\
\text { rj }\end{array}$ & $\begin{array}{c}\text { sdn } \\
\mathbf{0 4}\end{array}$ & $\begin{array}{c}\text { Masya } \\
\text {-rakat }\end{array}$ & total \\
\hline
\end{tabular}

\begin{tabular}{|l|c|c|c|c|c|}
\hline & $\begin{array}{c}\text { sisw } \\
\text { anan } \\
\text { d }\end{array}$ & & & & \\
\hline $\begin{array}{l}\text { Jumlah } \\
\text { Populasi }\end{array}$ & 127 & 356 & 313 & 422 & 1218 \\
\hline Proporsi & $\begin{array}{c}10.4 \\
3\end{array}$ & $\begin{array}{c}29.2 \\
3\end{array}$ & $\begin{array}{c}25.7 \\
0\end{array}$ & 34.65 & 100 \\
\hline $\begin{array}{l}\text { Jumlah } \\
\text { Responde } \\
\text { n }\end{array}$ & $\begin{array}{c}31.4 \\
0\end{array}$ & $\begin{array}{c}88.0 \\
1\end{array}$ & $\begin{array}{c}77.3 \\
8\end{array}$ & 104.33 & \\
\hline $\begin{array}{l}\text { Pembulat } \\
\text { an }\end{array}$ & $\mathbf{3 1}$ & $\mathbf{8 8}$ & $\mathbf{7 7}$ & $\mathbf{1 0 4}$ & $\mathbf{3 0 0}$ \\
\hline
\end{tabular}

Pengguna jalur pejalan kaki pada ruas jalan Ade Irma Suryani memiliki karakteristik yang berbeda-beda. Persentase karakteristik responden berdasarkan jenis kelamin disajikan pada Gambar 3. Responden berjenis kelamin laki-laki sebanyak 120 orang dan responden berjenis kelamin perempuan sebanyak 180 orang.

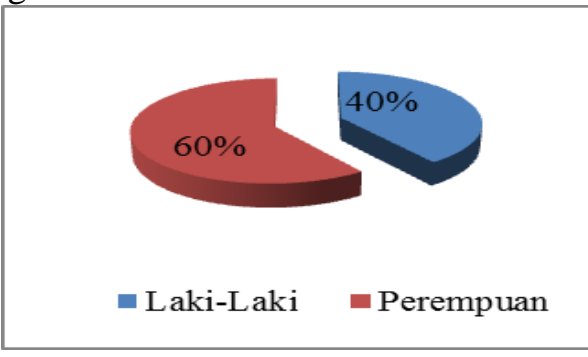

Gambar 3 Karakteristik responden berdasarkan jenis kelamin

Karakteristik responden berdasarkan usia yaitu responden berusia $\leq 12$ tahun sebanyak 77 orang, responden berusia 13 - 15 tahun sebanyak 88 orang, responden berusia $16-18$ tahun sebanyak 26 orang, responden berusia 19 - 25 tahun sebanyak 31 orang dan responden berusia > 26 tahun sebanyak 78 orang. Persentase karakteristik responden berdasarkan usia disajikan pada Gambar 4 .

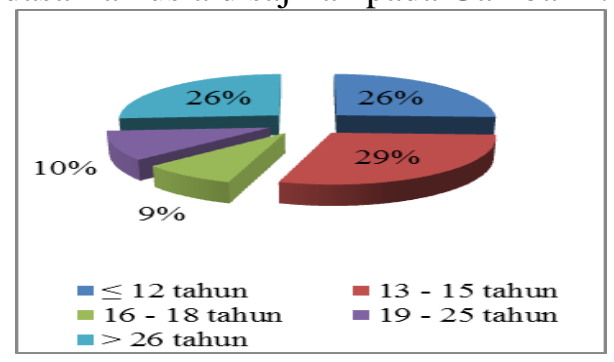

Gambar 4 Karakteristik responden berdasarkan usia 
Karakteristik responden berdasarkan tingkat pendidikan yaitu responden berpendidikan SD sebanyak 77 orang, responden berpendidikan SMP sebanyak 88 orang, responden berpendidikan SMA sebanyak 68 orang dan responden berpendidikan Diploma/S1/S2/S3 sebanyak 67 orang. Persentase karakteristik responden berdasarkan tingkat pendidikan disajikan pada Gambar 5.

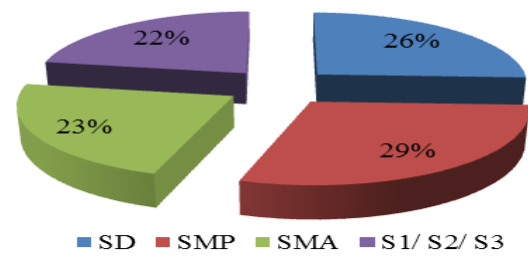

Gambar 5 Karakteristik responden berdasarkan tingkat pendidikan

Karakteristik responden berdasarkan pekerjaan yaitu responden bekerja sebagai PNS/TNI/POLRI/Guru sebanyak 32 orang, responden bekerja sebagai wiraswasta sebanyak 27 orang, responden bekerja sebagai pelajar/ mahasiswa sebanyak 222 orang dan responden bekerja lainnya sebanyak 19 orang. Persentase karakteristik responden berdasarkan pekerjaan disajikan pada Gambar 6.

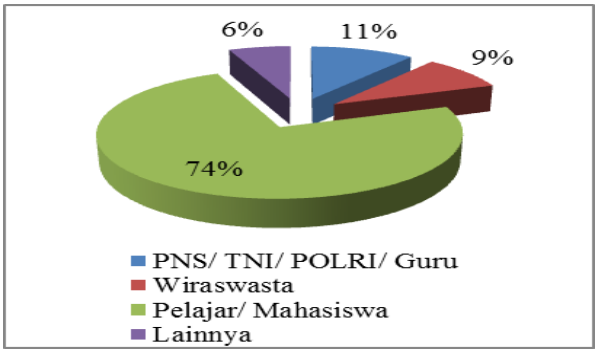

Gambar 6 Karakteristik responden berdasarkan pekerjaan

Karakteristik responden berdasarkan frekuensi penggunaan jalur pejalan kaki yaitu responden yang 4-7 kali seminggu atau setiap hari menggunakan jalur pejalan kaki sebanyak 221 orang, responden yang 1-3 kali seminggu menggunakan jalur pejalan kaki sebanyak 30 orang, responden yang sesekali menggunakan jalur pejalan kaki sebanyak 30 orang dan responden yang baru pertama kali menggunakan jalur pejalan kaki sebanyak 19 orang. Persentase karakteristik responden berdasarkan rekuensi penggunaan jalur pejalan kaki disajikan pada Gambar 7.

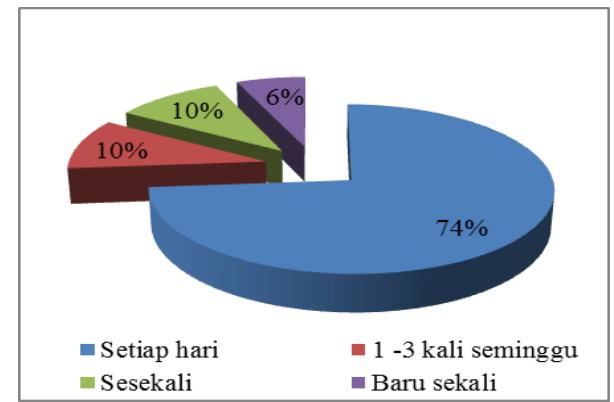

Gambar 7 Karakteristik responden berdasarkan frekuensi penggunaan jalur pejalan kaki

\section{Analisis Persepsi Masyarakat}

Berdasarkan hasil penilaian responden, maka dapat dihitung nilai rata-rata kinerja dan kepentingan indikator seperti pada Tabel 21. Penentuan indikator prioritas, dilakukan plotting nilai setiap indikator pada diagram kartesius pada Gambar 8.

Tabel 20 Perhitungan c-line indikator

\begin{tabular}{|c|c|c|c|c|c|}
\hline $\begin{array}{l}\mathbf{N} \\
\mathbf{0}\end{array}$ & Variabel & $\begin{array}{c}\text { Rata } \\
\text {-rata } \\
\text { kine } \\
\text { rja }\end{array}$ & $\begin{array}{c}\text { Rata- } \\
\text { rata } \\
\text { kepenti } \\
\text { ng-an }\end{array}$ & $\begin{array}{c}\mathbf{G a} \\
\mathbf{p}\end{array}$ & $\begin{array}{c}\text { tingk } \\
\text { at } \\
\text { ke- } \\
\text { sesu } \\
\text { ai-an } \\
\end{array}$ \\
\hline $\begin{array}{l}\text { ( } \\
1 \\
\text { ) }\end{array}$ & (2) & (3) & (4) & $\begin{array}{c}(5) \\
= \\
(4- \\
3)\end{array}$ & $\begin{array}{c}(6)= \\
(3 / 4) \\
x \\
100 \\
\%\end{array}$ \\
\hline 1 & $\begin{array}{l}\text { Jalur } \\
\text { dapat } \\
\text { dilalui } \\
\text { oleh } \\
\text { seluruh } \\
\text { pejalan } \\
\text { kaki } \\
\end{array}$ & 2.21 & 4.01 & $\begin{array}{c}1.8 \\
1\end{array}$ & $\begin{array}{c}54.9 \\
8\end{array}$ \\
\hline 2 & $\begin{array}{l}\text { Jalur } \\
\text { saling } \\
\text { terhubung }\end{array}$ & 3.45 & 3.93 & $\begin{array}{c}0.4 \\
8\end{array}$ & $\begin{array}{c}87.7 \\
1\end{array}$ \\
\hline 3 & $\begin{array}{l}\text { Tersedia } \\
\text { ruang } \\
\text { jalur } \\
\text { pejalan } \\
\text { kaki } \\
\text { berkebutu } \\
\text { han } \\
\text { khusus }\end{array}$ & 1.71 & 3.93 & $\begin{array}{c}2.2 \\
2\end{array}$ & $\begin{array}{c}43.5 \\
6\end{array}$ \\
\hline 4 & $\begin{array}{l}\text { Tersedia } \\
\text { ramp dan } \\
\text { marka } \\
\text { pejalan }\end{array}$ & 1.71 & 3.93 & $\begin{array}{c}2.2 \\
2\end{array}$ & $\begin{array}{c}43.5 \\
6\end{array}$ \\
\hline
\end{tabular}




\begin{tabular}{|ll|}
\hline Vol. 3 No.2 Juni 2020 & Rang Teknik Journal \\
http://jurnal.umsb.ac.id/index.php/RANGTEKNIKJOURNAL & \\
\hline
\end{tabular}

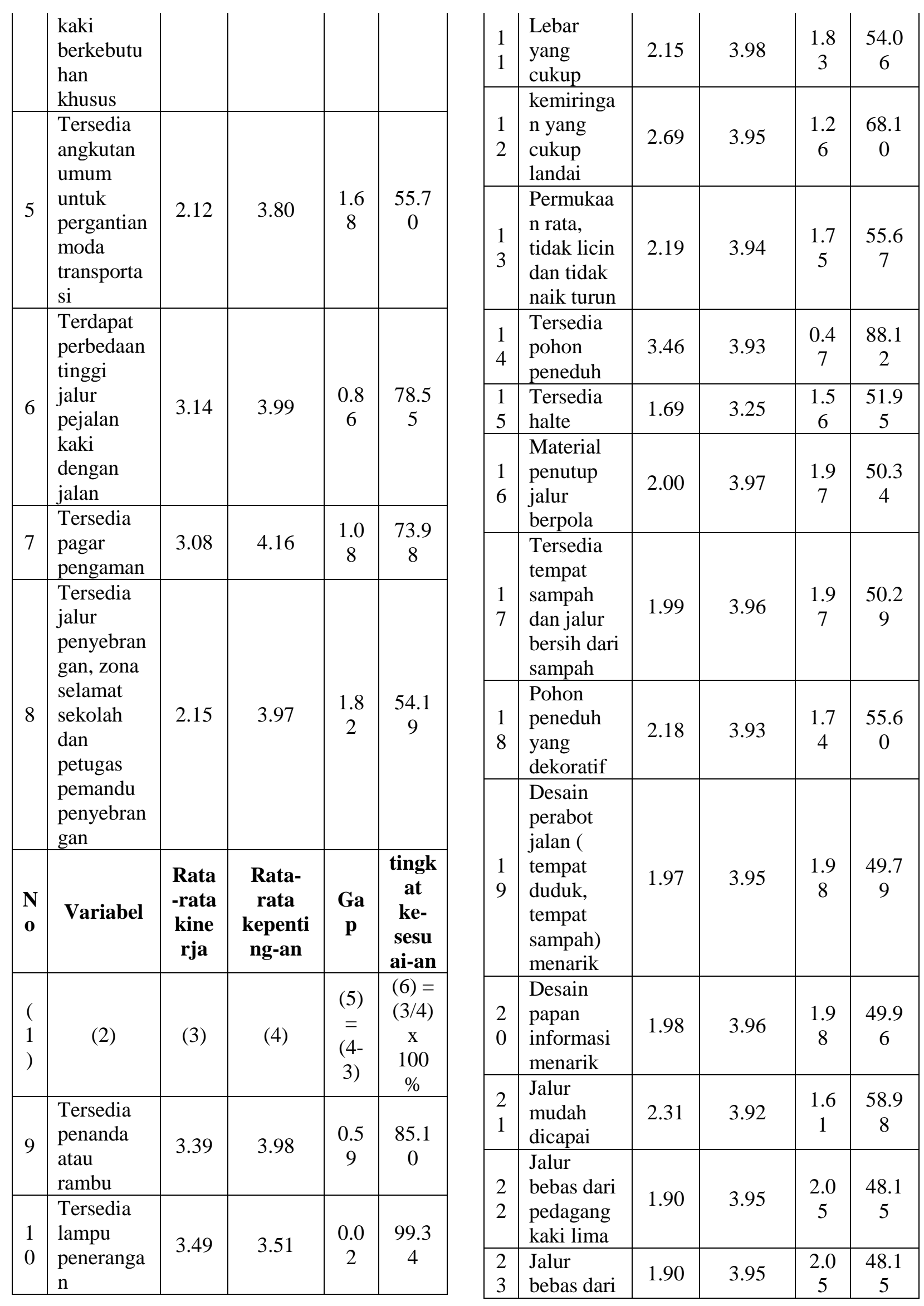


Vol. 3 No.2 Juni 2020

http://jurnal.umsb.ac.id/index.php/RANGTEKNIKJOURNAL

\begin{tabular}{|c|c|c|c|c|c|}
\hline & $\begin{array}{l}\text { parkir } \\
\text { kendaraan }\end{array}$ & & & & \\
\hline $\begin{array}{l}2 \\
4\end{array}$ & $\begin{array}{l}\text { Jalur } \\
\text { menerus/ } \\
\text { tidak } \\
\text { terputus }\end{array}$ & 2.25 & 3.93 & $\begin{array}{c}1.6 \\
8\end{array}$ & $\begin{array}{c}57.3 \\
4\end{array}$ \\
\hline $\begin{array}{l}2 \\
5\end{array}$ & $\begin{array}{l}\text { Tersedian } \\
\text { ya papan } \\
\text { informasi } \\
\text { (peta, } \\
\text { pengumu } \\
\text { man } \\
\text { kegiatan/ } \\
\text { event, } \\
\text { himbauan, } \\
\text { dll) }\end{array}$ & 1.93 & 3.92 & $\begin{array}{c}1.9 \\
9\end{array}$ & $\begin{array}{c}49.2 \\
3\end{array}$ \\
\hline $\begin{array}{l}2 \\
6\end{array}$ & $\begin{array}{l}\text { Tersedia } \\
\text { ruang } \\
\text { publik } \\
\text { untuk } \\
\text { berolahrag } \\
\text { a seperti } \\
\text { lari pagi }\end{array}$ & 1.63 & 3.92 & $\begin{array}{c}2.2 \\
9\end{array}$ & $\begin{array}{c}41.5 \\
8\end{array}$ \\
\hline $\begin{array}{l}2 \\
7\end{array}$ & $\begin{array}{l}\text { Tersedia } \\
\text { ruang } \\
\text { publik } \\
\text { untuk } \\
\text { berekreasi }\end{array}$ & 1.63 & 3.92 & $\begin{array}{c}2.2 \\
9\end{array}$ & $\begin{array}{c}41.5 \\
8\end{array}$ \\
\hline $\begin{array}{l}2 \\
8\end{array}$ & $\begin{array}{l}\text { Tersedia } \\
\text { ruang } \\
\text { publik } \\
\text { untuk } \\
\text { bersosialis } \\
\text { asi }\end{array}$ & 1.63 & 3.92 & $\begin{array}{c}2.2 \\
9\end{array}$ & $\begin{array}{c}41.5 \\
8\end{array}$ \\
\hline $\begin{array}{l}2 \\
9\end{array}$ & $\begin{array}{l}\text { Tersedia } \\
\text { taman } \\
\text { terbuka }\end{array}$ & 2.10 & 3.95 & $\begin{array}{c}1.8 \\
5\end{array}$ & $\begin{array}{c}53.1 \\
6\end{array}$ \\
\hline $\begin{array}{l}3 \\
0\end{array}$ & $\begin{array}{l}\text { Tersedia } \\
\text { fasilitas } \\
\text { interaksi } \\
\text { sosial } \\
\text { (perabot } \\
\text { jalan : } \\
\text { tempat } \\
\text { duduk dan } \\
\text { meja). }\end{array}$ & 1.51 & 3.92 & $\begin{array}{c}2.4 \\
1\end{array}$ & $\begin{array}{c}38.4 \\
9\end{array}$ \\
\hline & $C-L I N E$ & 2.25 & 3.91 & & \\
\hline \multicolumn{2}{|r|}{ JUMLAH } & $\begin{array}{c}67.5 \\
5\end{array}$ & 117.36 & & $\begin{array}{c}57.5 \\
6\end{array}$ \\
\hline
\end{tabular}

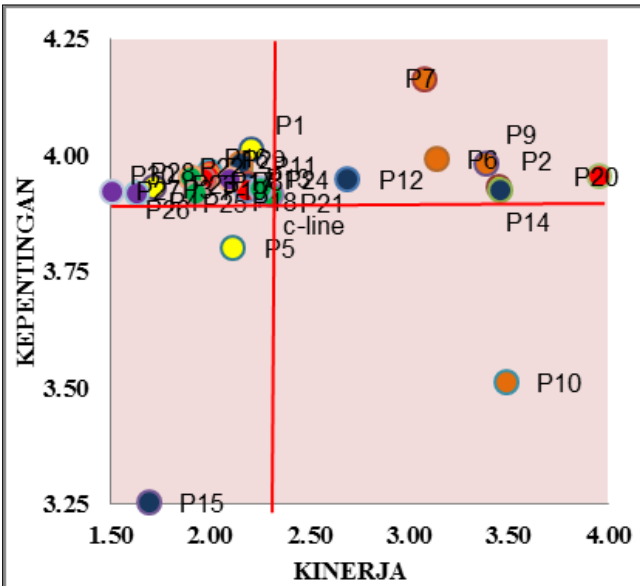

Gambar 8 Diagram IPA indikator

Dari diagram IPA diperoleh pengelompokkan indikator yaitu :

1. Prioritas utama adalah : P1. Jalur dapat dilalui oleh seluruh pejalan kaki, P3.. Tersedia ruang jalur pejalan kaki berkebutuhan khusus, P4. Tersedia ramp dan marka pejalan kaki berkebutuhan khusus, P8. Tersedia jalur penyebrangan, zona selamat sekolah dan petugas pemandu penyebrangan, P11. Lebar yang cukup, P13. Permukaan rata, tidak licin dan tidak naik turun, P16. Material penutup jalur berpola, P17. Tersedia tempat sampah dan jalur bersih dari sampah, P18. Pohon peneduh yang dekoratif, P19. Desain perabot jalan (tempat duduk, tempat sampah) menarik, P20. Desain papan informasi menarik, P21. Jalur mudah dicapai, P22. Jalur bebas dari pedagang kaki lima, P23. Jalur bebas dari parkir kendaraan, P24. Jalur menerus/ tidak terputus, P25. Tersedianya papan informasi (peta, pengumuman kegiatan/ event, himbauan, dll), P26. Tersedia ruang publik untuk berolahraga seperti lari pagi, P27. Tersedia ruang publik untuk berekreasi, P28. Tersedia ruang publik untuk bersosialisasi, P29. Tersedia taman terbuka dan P30. Tersedia fasilitas interaksi sosial (perabot jalan : tempat duduk dan meja).

2. Pertahankan kinerja adalah : P2. Jalur saling terhubung, P6. Terdapat perbedaan tinggi jalur pejalan kaki dengan jalan, P7.Ttersedia pagar pengaman, P9. Tersedia penanda atau rambu, P12. Kemiringan yang cukup landai dan P14. Tersedia pohon peneduh. 
3. Prioritas rendah adalah : P5. Tersedia angkutan umum untuk pergantian moda transportasi dan P15. Tersedia halte,

4. Terlalu berlebih adalah : P10. Tersedia lampu penerangan.

Nilai rata-rata kinerja dan kepentingan setiap variabel dapat dilihat pada Tabel 22 . Penentuan variabel prioritas, dilakukan plotting nilai setiap variabel pada diagram kartesius pada gambar 9.

Tabel 21 Perhitungan c-line variabel

\begin{tabular}{|c|l|c|c|c|c|}
\hline $\begin{array}{c}\mathbf{N} \\
\mathbf{0}\end{array}$ & Variabel & $\begin{array}{c}\text { Rata- } \\
\text { rata } \\
\text { kiner } \\
\text { ja }\end{array}$ & $\begin{array}{c}\text { Rata - } \\
\text { rata } \\
\text { ke- } \\
\text { pentin } \\
\text { g-an }\end{array}$ & Gap & $\begin{array}{c}\text { Tingk } \\
\text { at ke } \\
- \\
\text { sesuai } \\
\mathbf{- a n}\end{array}$ \\
\hline $\begin{array}{c}(1 \\
)\end{array}$ & $(3)$ & $(4)$ & $\begin{array}{c}(5)= \\
(4) \\
3)\end{array}$ & $\begin{array}{c}(6)= \\
(3 / 4) \mathrm{x} \\
100 \%\end{array}$ \\
\hline 1 & $\begin{array}{l}\text { Aksesibili } \\
\text { tas }\end{array}$ & 2.24 & 3.92 & 1.68 & 57.10 \\
\hline 2 & $\begin{array}{l}\text { Keselamat } \\
\text { an }\end{array}$ & 3.05 & 3.93 & 0.88 & 77.70 \\
\hline 3 & $\begin{array}{l}\text { Kenyama } \\
\text { nan }\end{array}$ & 2.44 & 3.81 & 1.37 & 63.96 \\
\hline 4 & $\begin{array}{l}\text { Keindaha } \\
\text { n }\end{array}$ & 2.02 & 3.95 & 1.93 & 51.19 \\
\hline 5 & $\begin{array}{l}\text { Kemudah } \\
\text { an }\end{array}$ & 2.06 & 3.93 & 1.87 & 52.36 \\
\hline 6 & $\begin{array}{l}\text { Interaksi } \\
\text { Sosial }\end{array}$ & 1.70 & 3.93 & 2.23 & 43.29 \\
\hline $\boldsymbol{c}$-line & $\mathbf{2 . 2 5}$ & $\mathbf{3 . 9 1}$ & & \\
\hline Jumlah & $\mathbf{1 3 . 5 1}$ & $\mathbf{2 3 . 4 7}$ & & $\mathbf{5 7 . 5 6}$ \\
\hline
\end{tabular}

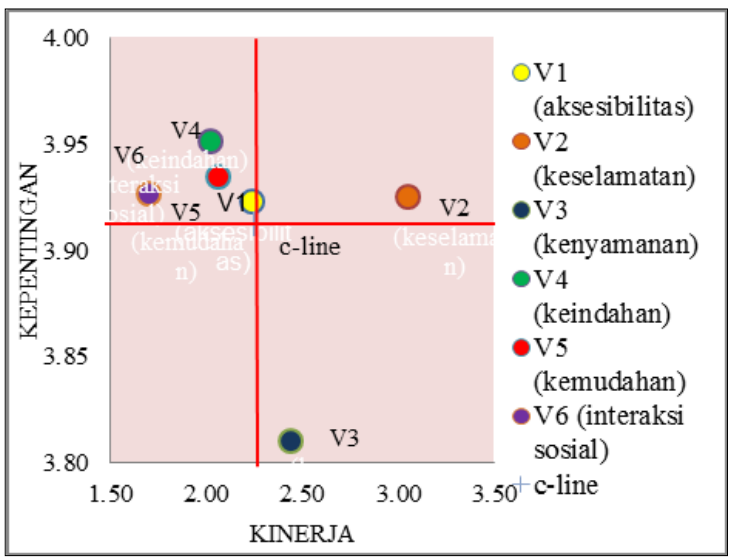

Gambar 9 Diagram IPA variabel

Dari diagram IPA diperoleh pengelompokkan variabel sebagai berikut :
1. Prioritas utama adalah : V1. aksesibilitas, V4. keindahan, V5. kemudahan dan V6. interaksi sosial.

2. Pertahankan kinerja adalah : V2. keselamatan

3. Terlalu berlebih adalah : V3. kenyamanan.

\section{PENUTUP}

Simpulan

Dari penelitian diperoleh kesimpulan :

1. Tingkat pelayanan jalur pejalan kaki pada jalan Ade Irma Suryani kota Payakumbuh pada sisi utara adalah A dengan indikator penilaian ruang sebesar $15.91 \mathrm{~m} 2 /$ orang, sedangkan tingkat pelayanan jalur pejalan kaki pada jalan Ade Irma Suryani kota Payakumbuh pada sisi selatan adalah B dengan indikator penilaian ruang sebesar $4.50 \mathrm{~m} 2 /$ orang.

2. Dari hasil analisis diperoleh tingkat kesesuaian antara kinerja/ kenyataan tingkat pelayanan jalur pejalan kaki dengan kepentingan/ harapan masyarakat terhadap tingkat pelayanan jalur pejalan kaki sebesar $57.56 \%$.

3. Variabel dengan prioritas utama yang memerlukan penanganan adalah a. aksesibilitas, b. keindahan, c. kemudahan dan d. interaksi sosial. Variabel keselamatan hanya perlu dipertahankan kinerjanya, sedangkan variabel kenyamanan tidak diprioritaskan penanganannya.

4. Secara umum diperlukan rencana penanganan untuk indikator tingkat pelayanan jalur pejalan kaki pada kawasan pendidikan jalan Ade Irma Suryani kota Payakumbuh seperti penyesuaian kembali dimensi jalur pejalan kaki dengan standar, penggantian material penutup permukaan jalur pejalan kaki, penyediaan dan penambahan serta pembenahan penempatan sarana jalur pejalan kaki (rambu, marka, perabot jalan), penertiban parkir dan pedagang kaki lima dan lainnya.

\section{Saran}

Saran untuk penelitian selanjutnya :

1. Untuk penilaian tingkat kinerja dengan skala sangat baik, baik, cukup baik, tidak baik dan sangat tidak baik, seharusnya dilakukan pendefenisian yang jelas dan pembobotan terukur. 
2. Pengolahan kuesioner sebaiknya dibedakan untuk masing-masing sisi jalur pejalan kaki, karena kondisi jalur pejalan kaki pada sisi utara dan selatan sangat berbeda, sehingga penilaian responden lebih spesifik sesuai dengan sisi jalur pejalan kaki yang dilewatinya.

\section{DAFTAR PUSTAKA}

Cadima, E. L., Caramelo, A. M., Dias, M. A., de Barros, P. C., Tandstad, M. O. \& de Leiva-Moreno, J. I. (2005). Sampling Methoda Applied :to Fisheries Science : Manual. Rome : Publishing Management Service Information Division FAO.

Highway Capacity Manual. (2000). Washington DC : Transportation Research Board.

Irawan, B. (2017). Analisis karakteristik dan tingkat pelayanan fasilitas pejalan kaki dikawasan pasar Gede kota Surakarta. EJurnal Matriks Teknik Sipil, 30-37.

Ferdiansyah, S. (2017). Identifikasi tingkat pelayanan fasilitas pejalan kaki dikawasan komplek Gor H. Agus Salim kota Padang. Jurnal Teknik PWK, 1(3), 1-13.

Kementrian Pekerjaan Umum. (2014). Peraturan Menteri Pekerjaan Umum nomor 03/PRT/M/2014 tentang pedoman perencanaan, penyediaan, dan pemanfaatan prasarana dan sarana jaringan pejalan kaki di kawasan perkotaan. Jakarta.

Limpong, R. (2015). Pemodelan fasilitas arus pejalan kaki (trotoar). Jurnal Sipil Statik, 3(3), 212-220.

Martilla, J. A., James , J. C. (1977). Importance performance analysis. Journal of Marketing.

Simanjuntak, M. R. A. (2011). Analisis pengaruh kualitas area pedestrian terhadap kemudahan akses pengunjung bangunan mal di jalan Asia Afrika. Jurnal Ilmiah Media Engineering, 1(2), 135-143.

Walikota Payakumbuh. (2012). Peraturan daerah Kota Payakumbuh nomor 1 tahun 2012 tentang Rencana Tata Ruang Wilayah Kota Payakumbuh Tahun 2010 $-2030$.

Wiyana, P. P. (2010). Analisis fasilitas pejalan kaki pada ruas jalan Gajah Mada
Denpasar Bali. Jurnal Ilmiah Teknik Sipil, 4(1), 82-95. 